\title{
Biografi og verk. Kommunikasjonsprosesser i forfattermuseer
}

\section{En innledning}

\author{
ULRIKE SPRing \& JOHAN SCHIMANSKI
}

Museumstudier har i de siste årene lagt økt vekt på medienes rolle for kommunikasjonsprosessene i museer (f.eks. Drotner et al. 2018). Medier skaper kommunikasjon utover museenes grenser og knytter sammen historiske og andre kontekster. I dette spesialnummeret tar vi som utgangspunkt at museer er deler av kompleks medieensemble der kommunikasjonen går på kryss og tvers og forstyrrer dikotomier som det indre og det ytre, eller fortid og fremtid. Ulike verktøy tas i bruk for å kommunisere med omverden og skaper, bekrefter og utfordrer gamle og nye fortellinger. Forfattermuseer, eller mer generelt personmuseer, er særdeles spennende cases når en skal undersøke ulike former for krysskommunikasjon, siden "det ytre" er en integrert del av museets egenart. Forfatteren og verket hennes er hovedaktørene i museets fortelling, og selv om forfatteren i de aller fleste tilfellene ikke er tilstede fysisk, utgjør hennes immaterielle tilstedeværelse museets hovedinnhold. Samtidig skaper hennes litteratur hele tiden nye tråder til andre verdener, enten de er reelle eller fiktive.

Spørsmål om museenes mangfoldige kommunikasjonsprosesser sto sentrale i det internasjonale og tverrfaglige forskningsprosjektet
TRAUM - Transforming Author Museum (2016-2019) som spesialnummeret er ett resultat av. ${ }^{1}$ Prosjektet har brakt sammen forskere ved norske forskningsmiljøer ved Høgskulen på Vestlandet (Sogndal) og Universitetet i Oslo, i tillegg til eksterne deltakere fra flere land. Museologer, historikere, kulturhistorikere, litteraturvitere, turismeforskere, museumsarbeidere, en didaktiker og en litterær forfatter har arbeidet sammen og kombinert både kvalitative og kvantitative metoder. Vi har gjort undersøkelser av et utvalg museer i Norge, Europa, og Sør-Afrika; vi har også tatt inn et bredt utvalg museer i Europa, Japan og USA for å vise mangfoldet i forfattermuseumssjangeren. Kunnskapsoverføring og kunnskapsutveksling mellom høyskole-/universitetsforskere og museumsarbeidere/forfattere har vært en sentral del av prosjektet, med ønske om at våre resultater vil være til nytte for museumsarbeidere og forskere både nasjonalt og internasjonalt.

I prosjektet har vi søkt å belyse gjeldende praksis for forfattermuseer ut fra samtidige og historiske perspektiver, gjennom historiske undersøkelser, lesninger av nåtidige utstillinger og publikumsundersøkelser, med sikte på å 
utvikle nye tolkninger av museer som rom for kunnskapsoverføring og kulturproduksjon. Vi har særlig vært opptatt av å undersøke historiske og pågående prosesser knyttet til demytisifering av forfattermuseenes rolle og utvidelsen av sjangeren forfattermuseum i et landskap som nå strekker seg til forfattersentre, litteraturmuseer, litterære utstillinger, temaparker, tverrnasjonale forfattermuseer, osv. Disse tendenser har delvis gått hånd $\mathrm{i}$ hånd med samfunnets behov for demokratisering. Formuleringen av temaet for ICOMs (International Council of Museums) 25. allmenne konferanse i Kyoto i 2019 omtalte museer som "cultural hubs". Samfunnet inviteres inn og museet flyttes ut. Nye typer besøkende tar veien innom museene; forfattermuseer oppfattes ikke lenger som "bare" valfartssteder. Museenes identitetsskapende og ofte nasjonsbyggende funksjon er under endring.

I tillegg til et fokus på disse temaene, har vi i prosjektet også forsøkt å utvikle nye teoretiske modeller for analyse av kommunikasjonsprosesser i forfattermuseer, og å knytte disse til museenes praksis og muligheter for nye utstillingsstrategier. Det er dette som er tema for dette spesialnummeret. Forfattermuseer preges av et komplekst forhold mellom litteratur og biografi, mellom forfatterens tilstedeværelse og fravær, og av den besøkendes rolle som både amatørbiograf og leser. Slike spenninger er typisk for forfattermuseenes mangfoldige kommunikasjonsprosesser. Museet kan være en del av leseopplevelsen, og dermed del av det posthume litterære verket. Vi som har bidratt her, ønsker å ta disse forståelsesrammene som utgangspunkt for dette spesialnummeret og spørre - fra våre perspektiver som museologer, historikere og litteraturvitere - hva som skjer når vi ser på forfattermuseet som en kompleks medierte kommunikasjon mellom forfatteren, museet, det litterære verket og den besøkende.
Ofte skaper disse aktører spenninger i forfattermuseer. Hvordan skjer dette i et historisk perspektiv (Hendrix) og hvordan påvirker historiske narrativer disse relasjonene (Hoel)? Hvilke metodiske muligheter finnes for å analysere dette komplekse forholdet (Schimanski \& Spring, Aarbakke)? Hvilke utfordringer finnes når en skal skille mellom litteratur og forfatter (Egeland), og hvordan påvirker forfatterens biografi resepsjonen av verket, og omvendt (Egeland, Hoel og Aarbakke)?

Vi avrunder spesialnummeret med en samtale om teoretiske og praktiske hensyn som preger utstillingsarbeid om forfattere og litteratur, der to av TRAUM-prosjektets medarbeidere diskuterer mulighetene i forfatter- og litteraturmuseer sammen med to produsenter av litterære utstillinger (Gfrereis, Neundlinger, Schimanski \& Spring).

Bidragene viser at det finnes et mangfold av kommunikasjonsverktøy på museet som kan benyttes for å skape ulike fortellinger om forfatteren og verket hennes og dermed skape stadig nye forbindelser mellom forfatter og verk. Hendrix fremhever både guidebøker skrevet av aktører utenfor museet og forfatterens egne ønsker om musealisering, som bidrag til å endre forfatterhjem til husmuseer. Musealiseringen førte samtidig til at interessen for forfatteren som person økte og at litteraturen kom i bakgrunnen på disse stedene. Hans eksempler er fra Italia, Frankrike og England på 1700- og 1800-tallet. Disse danner en blåkopi for forfatterhjemmuseer i ettertiden, der forfatteren ofte tildeles en større rolle enn hans eller hennes litteratur. Dette er også noe som Egeland, Hoel og Aarbakke viser i sine bidrag. Alle tre tar utgangspunkt i case-studier i norske forfattere, men med ulikt fokus på kommunikasjonsverktøyene som brukes for å musealisere dem.

Egeland tar utgangspunkt i tiden før et mu- 
seum etableres, når avisrapporter og museumspolitiske dokumenter over den planlagte grunnleggelsen er det viktigste kommunikasjonsverktøyet mellom de ulike aktørene og med omverdenen. Målet om å lage forfattermuseer om Knut Hamsun i Nord- og henholdsvis i Sør-Norge førte bare delvis frem. Hennes eksempler viser at etableringsprosessen kan hindres - og til og med stoppes - når det finnes kontroversielle bilder av forfatteren og en vellykket kommunikasjon ikke kan opprettes mellom ulike interessegrupper. Hennes bidrag peker også til et annet sentralt tema som preger kommunikasjonsprosesser på museet og med omverden: Spenningen mellom biografi og litteratur. I hvor stor grad skal et museum kommunisere problematiske sider ved en forfatters biografi til omverden, og på hvilken måte? Hvilken betydning har biografi for resepsjonen av litteratur? Hamsunsenteret i Nord-Norge er et sjeldent eksempel på en forfatterutstilling der biografien overskygges av verket, noe som man også kan se i den litteratur-inspirerte utformingen av selve bygget (for en grundig analyse av rollen forfatteren får tildelt i senteret, se Aarbakke 2019).

Hoel fokuserer på fire godt etablerte museer i Sør-Vest- og Sør-Øst-Norge som alle er viet én og samme forfatter eller forfatterektepar: Arne og Hulda Garborg. Han viser hvordan utvalgte historiske narrativer om forfatternes liv og verk preger museets kommunikasjon til omverdenen - og at ulikt eierskap av museene også medvirker til å skape ulike fortellinger om sosial posisjon, regional identitet og kjønn og forfatterskap. Et sentralt kommunikasjons-"verktøy" i tre av de fire analyserte Garborgmuseene er omviseren som bestemmer den hegemoniale museumsfortellingen om forfatterekteparet og verkene deres. Samtidig bidrar objekter som forfatternes graver og gamle møbler, men også digitale verktøy som
QR-koder, til å åpne opp for andre fortellinger. Særlig de digitale kommunikasjonsverktøyene bidrar til at museet og den besøkende kan flytte seg raskt fra biografi til litteratur og tilbake, og det er her museene kanskje har den største utviklingsmuligheten når de skal leke med spenningen mellom biografi og verk.

Det er husets og utstillingens materialitet Aarbakke legger vekt på i sin aktør-nettverksteori-inspirerte analyse av utstillingen i Vest-Norge tilegnet dikteren Olav H. Hauge. Som Hoel tar hun utgangspunkt i museets egne fortellinger, men trekker seg selv aktivt inn i analysen som besøkende og dermed som del av kommunikasjonsnettverket. Hun diskuterer hvordan interaksjonen hennes med husets gjenstander som vindu, bord og bokhylle kan bidra til å synliggjøre ulike måter museet kommuniserer med omverdenen på. Differansen mellom litteratur og forfatter, mellom den besøkende og museet oppheves og nye fortellinger kan tre frem.

Spørsmålet om hvordan man kan analysere den komplekse spenningen mellom de ulike aktørene - museum og besøkende, forfatter og litteratur - står sentralt i Schimanski \& Springs bidrag. Litteratur- og språkviteren Roman Jakobsons kommunikasjonsmodell tillempes og anvendes på forfatterhjemmuseer, der særlig Strindbergsmuseet i Stockholm brukes som case for å teste tilnærmingen. Her fungerer altså en bestemt metode som kommunikasjonsverktøy med formålet om å forstå de ulike kommunikasjonsprosessene.

Som bidragene viser på hver sin måte, kan kommunikasjon fremmes eller forhindres ved å ta ulike grep eller foreta ulike tolkninger. Kunnskapsproduksjonen foregår i et komplekst felt der noe fremheves og noe ikke nevnes. At dette feltet er åpent og at det stadig utvikles nye former for kommunikasjon på litterære utstillinger og forfattermuseer understrekes $\mathrm{i}$ 
den avsluttende diskusjonen mellom TRAUMprosjektets medarbeidere Ulrike Spring og Johan Schimanski og utstillingskuratorene Heike Gfrereis ved Deutsches Literaturarchiv Marbach og Helmut Neundlinger, skaperen av den nåværende utstillingen i W. H. Audenmuseet i Kirchstetten.

\section{Noter}

1. Prosjektet var finansiert av Norges Forskningsråd, nummer 251225. For mer informasjon se prosjektets hjemmeside https://traum.hisf.no/.

\section{REFERANSER}

Drotner, Kirsten, Vince Dziekan, Ross Parry \& Kim Christian Schrøder (red.) 2018. The Routledge Handbook of Museums, Media and Communication. London: Routledge.

Aarbakke, Thea 2019. Forfattermuseumsfunksjonene. Musealiserte relasjoner mellom liv og litteratur. En studie av Hamsunsenteret, Bjerkeboek - Sigrid Undsets hjem og Hauge-senteret. PhD-avhandling. Universitetet i Oslo.
Ulrike Spring, dr.phil., førsteamanuensis
Institutt for arkeologi, konservering og historie

Universitetet $i$ Oslo

Postboks 1008 Blindern

NO-0315 Oslo, Norge

www.hf.uio.no/iakh/personer/vit/historie/fast/ ulrikesp

Institutt for samfunnsvitskap

Høgskulen på Vestlandet campus Sogndal

Postboks 133

NO-6851 Sogndal, Norge

Johan Schimanski, dr.art., professor

johan.schimanski@ilos.uio.no

Institutt for litteratur, områdestudier og europeiske språk

Universitetet i Oslo

Postboks 1003 Blindern

NO-0315 Oslo, Norge

www.hf.uio.no/ilos/personer/vit/johanhsc 